\title{
APPLICATION OF UAV SURVEYS FOR EVALUATING THE PRODUCTIVITY LEVELS OF TRADITIONAL AND MECHANISED FARMERS IN A CUSTOMARY LAND TENURE SYSTEM
}

\author{
Dupe N. Olayinka ${ }^{1,2}$, Kayode L. Omolaye ${ }^{1,3}$, Adewale J. Ilesanmi ${ }^{1,4}$, Chukwuma J. Okolie ${ }^{1 *}$ and Ikenna D. Arungwa \\ ${ }^{1}$ Department of Surveying and Geoinformatics, Faculty of Engineering, University of Lagos, Lagos State, Nigeria \\ ${ }^{2}$ Federal School of Surveying, Oyo State, Nigeria \\ ${ }^{3}$ Geospatial Research Limited, Lagos State, Nigeria \\ ${ }^{4}$ Office of the State Surveyor-General, Lagos State, Nigeria \\ ${ }^{5}$ Department of Surveying and Geoinformatics, Faculty of Engineering, Abia State University, Abia State, Nigeria
}

KEY WORDS: Remote Sensing, Unmanned Aerial Vehicle, Orthomosaic, Customary Land Tenure, Mechanisation, Agriculture, Crop Field Fraction, Crop Yield Index.

\begin{abstract}
:
In most of Nigeria's rural communities, land holdings are small and uneven; and this impacts significantly on their mechanisation potentials. This fragmented nature of the farmlands also inhibits the creation of an effective land market. This study utilised a digital orthomosaic generated from an Unmanned Aerial Vehicle (UAV) survey in evaluating the productivity levels of traditional and mechanised farmers in Okeho Community of Oyo State, South-Western Nigeria. The aerial survey was conducted with a DJI Phantom 4 Professional UAV covering 250 acres of traditional and mechanised farmlands to produce a very high resolution orthomosaic at $6 \mathrm{~cm}$ spatial resolution. Sixty-three respondents (61 traditional farmers and 2 mechanised farmers) were also interviewed using questionnaires. Their responses were keyed into a database with the Open Data Kit (ODK) data collector. The orthomosaic was classified into farmland units and a database of the farmers land holdings was created in ArcGIS software. Some parameters influencing their productivity were computed - Crop Field Fraction (CFF) and Crop Yield Index (CYI). The results showed that very few farmers had a shared equity on land (only 3\%); most farms were acquired under freehold or lease. Also, only $1 \%$ of their farm sizes was larger than 5 acres. There was a sharp disparity in the crop field fraction (traditional farms - 32.2; mechanised farms - 68.8), and the productivity from the mechanised farmers surpasses that of the traditional farmers. It is recommended that the Government should support cluster farming systems among farmers to boost productivity.
\end{abstract}

\section{INTRODUCTION}

It is generally agreed that there is a connection between the existing land tenure systems and level of productive agriculture obtainable in any given area. Research on land tenure systems in relation to agricultural productivity is imperative in Nigeria. It becomes more important as about $97 \%$ of the country's landmass is undocumented. Furthermore, it has been reported that about $95 \%$ of agricultural lands in Nigeria are not titled, effectively making them unfit to be used as collateral for any form of financial transactions (Anyim, 2014; Federal Ministry of Agriculture and Rural Development, 2016; Obayelu et al., 2017).

Several authors have assessed agricultural productivity using different methods (e.g., Dlamini and Masuku, 2011; Schneider and Gugerty, 2011; Benin, 2016). Field observation with Global Navigation Satellite Systems (GNSS) for field area and boundary delineation can be costly in effort and time. Satellite imageries are often limited in spatial and temporal resolution as the satellites are usually not readily available for data collection when exactly needed. Optical satellite imageries are also affected by cloud cover, and there is a waiting time between the acquisition and delivery time, unlike Unmanned Aerial Vehicles (UAVs) which can deliver very high resolution imagery at the desired spatial resolution in a timely and cost-effective manner (Graesser and Ramankutty, 2017; Tsouros et al., 2019). UAVs have thus proven to be time and cost-effective remote-sensing platforms for delineation of field areas and boundaries of agricultural fields. The prospects of leveraging on this technology for smart agriculture are immense with the farmer/operator having full control of the devices which are deployable in variable weather conditions capturing high resolution images (Kumar et al., 2020). Today, the usage of UAVs in farming and agriculture is expanding faster because they are more affordable and easier to use (Frankelius et al., 2017). UAVs offer the opportunity to improve crop yield, crop health monitoring, crop damage assessment, and soil and field analysis. The field assessment and monitoring task is easier, closer, and precise, reducing cost and time (Hunt et al., 2018). UAV technologies also enable data-driven and prompt decision making by the farmer and ultimately leads to increased productivity. The data gathered can be accessed by the farmers and other stakeholders via cloud-based platforms remotely or from applications on their smart devices. Depending on the project requirements, UAVs can be equipped with different types of sensors such as RGB, hyperspectral (HS), and multispectral (MS) for various operations.

The application of UAV surveys in agriculture has been well documented (e.g. Christiansen et al., 2017; Tsouros

*Corresponding author. Email addresses: cokolie@unilag.edu.ng, cjohnokolie@gmail.com 
et al., 2019; Radoglou-Grammatikis et al., 2020). The advantages include three-dimensional mapping and real-time data capture with high spatial resolution, rapid
Ile, Iwere - Oke and Ilaji - Oke. The climate in Oyo State favours the cultivation of crops like maize, yam, cassava, millet, rice, plantains, cocoa, palm produce, cashew etc.

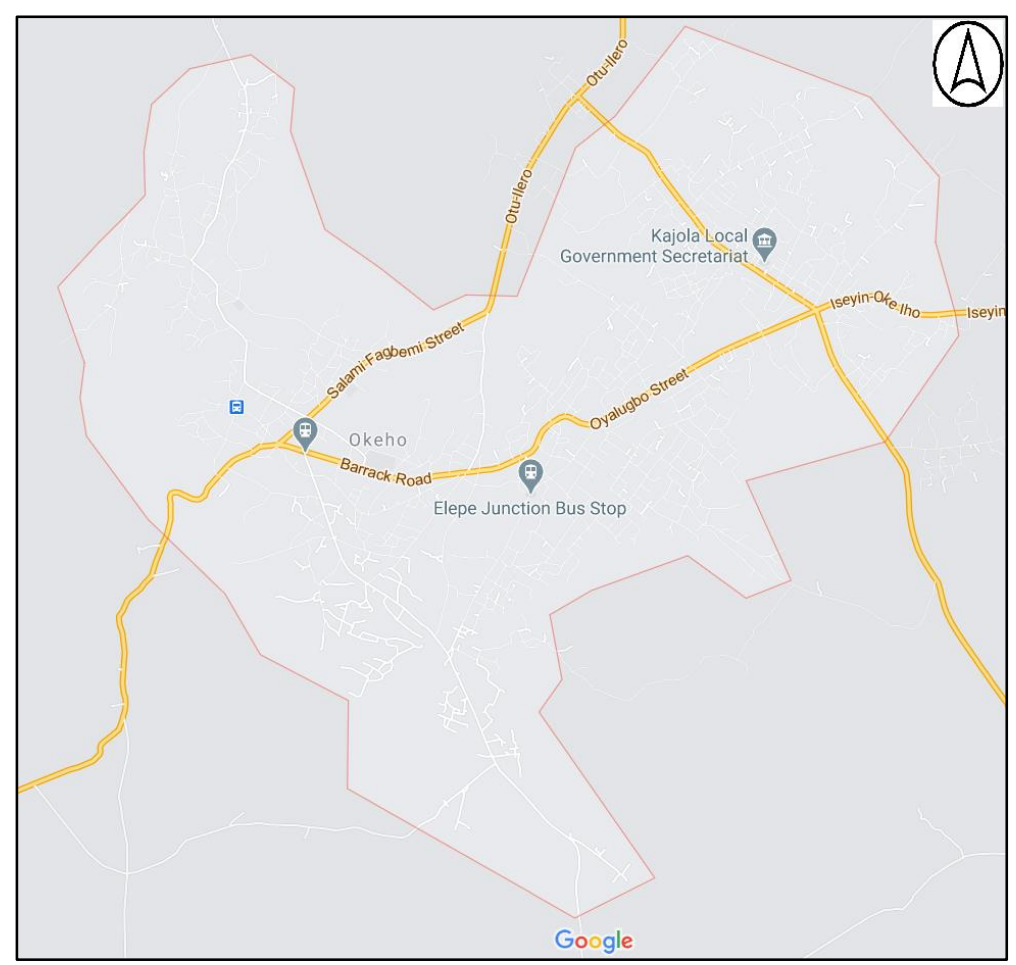

Figure 1. Map showing location of Okeho community in Kajola LGA, Oyo State, Nigeria

data collection for site inspection, mapping and surveillance (Koeva et al., 2018; Ruwaimana et al., 2018; Iizuka et al., 2018; Lahoti et al., 2019; Gbopa et al., 2021). Additional benefits of using UAVs in agriculture include input optimisation (fertilizer, water, seeds); faster reaction to threats from weeds, fungi and pests; precise application of plant treatments; and precise estimation of crop yield (European Agricultural Machinery Association, 2016).

Deliverables of UAV surveys include three-dimensional (3D) point clouds, digital orthomosaics and digital surface models (Gbopa et al., 2021). The full potential of UAVs in agriculture has not been fully explored in Nigeria. The present study utilised a digital orthomosaic generated from a UAV survey in evaluating the productivity levels of traditional and mechanised farmers in Okeho Community of Oyo State, South-Western Nigeria. The UAV mapping was combined with a questionnaire survey of 61 traditional farmers and 2 mechanised farmers. This enabled the comparative assessment of productivity levels in customary land tenure system across two types of agricultural practice (mechanised and traditional).

\subsection{Study Area}

Okeho community is the headquarters of Kajola Local Government Area (LGA) in Oyo State, Nigeria, West Africa. The community is geographically located between latitudes $8^{\circ} 02^{\prime} 02^{\prime} ' \mathrm{~N}-8^{\circ} 04^{\prime} 03^{\prime \prime} \mathrm{N}$ and longitudes $3^{\circ} 20^{\prime} 51^{\prime}$ 'E - $3^{\circ} 20^{\prime} 30^{\prime}$ 'E. Farming is the major occupation of Okeho community and environs. Okeho is bounded by other major towns such as Ilero, Ilua, Ayetoro - Oke, Isemi
Temperatures are constantly high averaging between $25^{\circ} \mathrm{C}$ and $35^{\circ} \mathrm{C}$ especially within Oyo North zone. Figure 1 shows a map of the study area.

\section{MATERIALS AND METHODS}

A UAV survey of mechanised and traditional farmlands was carried out and questionnaires were administered to both mechanised and small-scale farmers in 2019.

\subsection{UAV and Ground Survey}

The DJI Phantom 4 UAV was deployed to capture aerial images of the farmland. The UAV has an on-board camera with a complementary metal-oxide semiconductor (CMOS) sensor of $1 / 2.3^{\prime \prime}$ and a lens with a $94^{\circ}$ field of view (FOV) and $8.8 \mathrm{~mm} / 24 \mathrm{~mm}$ ( $35 \mathrm{~mm}$ format equivalent) focal length. The boundary of the project area was mapped using a handheld Global Positioning System (GPS) device which was converted to Keyhole Markup Language (KML) format and then saved on Drone Deploy software for the flight plan. Each flight plan was divided into two missions and take-off points were set. The flight was conducted at an altitude of $150 \mathrm{~m}$ to prevent interference and collision with trees. The UAV was maintained at a speed limit of $15 \mathrm{~ms}^{-1}$, flight direction of $126^{\circ}$ and image overlaps were set at $75 \%$ fore and $65 \%$ side. This sequence of overlapped images was collected for both the smallscale farmland and the mechanised farmland. After the flight, a total of 542 images were downloaded covering 


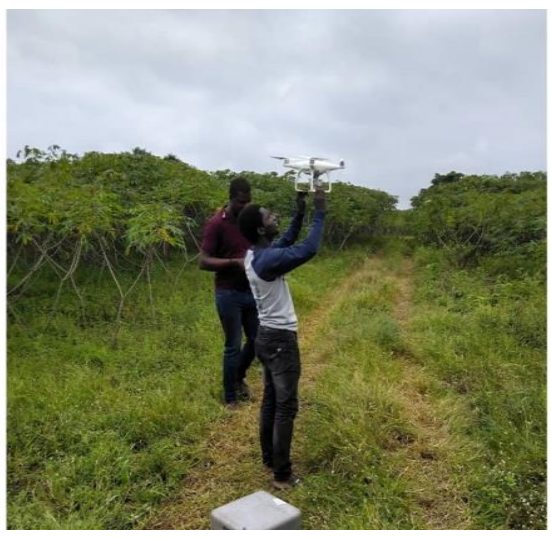

Figure 2. UAV survey in progress

the two project sites. The raw photos captured were downloaded and processed with Pix4D Mapper software. The main stages of the Pix4D Mapper processing workflow are well documented in Iheaturu et al. (2020) and Gbopa et al. (2021). Essentially, it involves the initial processing and image alignment, the point cloud and mesh processing, and the generation of the orthomosaic. The orthomosaic was produced at a ground resolution of $6 \mathrm{~cm}$. Figure 2 shows the UAV survey in progress.

\subsection{Questionnaire Survey}

A structured questionnaire was designed in digital format using the Open Data Kit (ODK) Collect v1.23.0. ODK Collect is a mobile application for data collection in digital format. A total number of 63 farmers were captured in the survey (small scale traditional - 61; mechanised - 2), based on a random sampling technique. Consequently, all data were collected and saved on a mobile phone internal memory and later exported into a spreadsheet. The questionnaire was sectioned into three major categories: background/household characteristics, socio-economic characteristics and productivity characteristics of farmers.

\subsection{Quantitative Analysis}

The descriptive analysis was carried out for the land tenure systems (e.g., freehold, lease and shared equity), farmer characteristics (name, gender, age, location and education) and farmland characteristics (farmland size, farmland cultivated, crops). The relationship between the land tenure systems, farmer's characteristics and the farmland characteristics was also assessed, and the land productivity was evaluated. The orthomosaic was also digitised to determine the fraction of the cropped areas. The formula for the crop field fraction (CFF) is given below in equation 1 .

Crop Field Fraction $(C F F)=$ $\frac{\text { No.of pixels classified as cropped }}{\text { Total no.of pixels }} \times 100$

Land productivity was expressed in terms of physical output, such as tons of maize, which corresponds to crop yields. Crop yield index is widely used to compare yields of a number of crops on a given farm with the average yields of the same crops on another farm. Thus, land productivity was measured as the ratio between the area occupied by the crops and the total land used in agriculture. The formula for crop yield index is shown below in equation 2 .

Crop Yield Index $(C Y I)=\frac{\sum_{i=1}^{n}\left(\frac{y}{y i o}\right) A i}{\sum_{i=0}^{n}(A i)}$

where: $\quad i=1,2,3, \ldots \mathrm{n}$; number of crops considered in a unit area.

$\mathrm{A} i=$ the weight of crop $i$, denoted by the area under the crop as a percentage of total cropped.

$\mathrm{y}=$ the yield per acre of crop $i$ in a farm area (traditional farmland).

$\mathrm{y}_{i o}=$ the average yield per acre of crop $i$ in a base farm area (mechanised farmland).

\section{RESULTS AND DISCUSSION}

\subsection{Digital Orthomosaic}

Figure 3 shows images captured over the traditional and mechanised farms while Figure 4 shows the digital orthomosaic of traditional and mechanised farming systems in Okeho community.
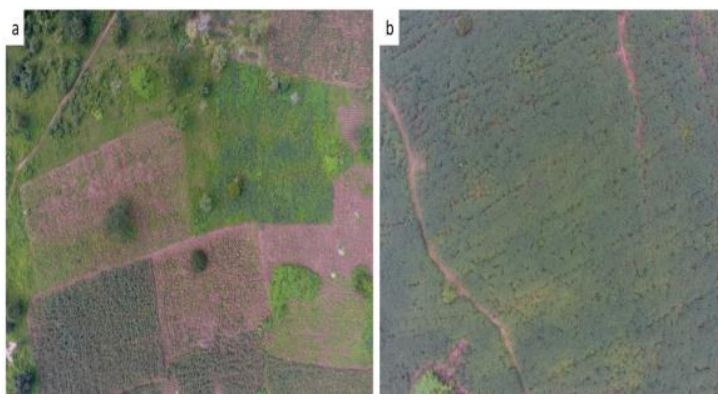

Figure 3. UAV images showing (a) traditional smallscale farm, and (b) mechanised farm

\subsection{Farmland Characteristics and Productivity}

Table 1 shows the demographic and socioeconomic characteristics of the farmers. Three major land tenure practices were identified: $66.7 \%$ of the farmers operate a freehold tenure system, $28.6 \%$ operate a leasehold tenure system while $4.8 \%$ operate shared equity. Land titles were classified into purchase agreement/receipt, no title, lease agreement, community issued certificate, and title deed/survey plan/certificate of occupancy. The result shows that $55.6 \%$ of the farmers have no title, $31.7 \%$ have purchase agreement/receipt, $8 \%$ have lease agreement, $3.2 \%$ have title deed/survey plan/certificate of occupancy whereas $1.6 \%$ have community issued certificates. In terms of the farm size, $31.7 \%$ of the farmers have farm sizes below 1 acre, $42.9 \%$ are between $1-2.5$ acres, $9.5 \%$ are between 2.5 - 5 acres, $12.7 \%$ range from 5 - 10 acres while $3.2 \%$ of the of the farmers have farm sizes above 10 acres. Lastly, $60.3 \%$ of the farmers put their farm produce on sale for money, $27 \%$ use their farm produce for home consumption, while $12.7 \%$ use their farm produce as an 
exchange for other products. Two major crops were identified in the farms: maize and cassava. freehold or lease. Also, a small percentage of their farm sizes was larger than 5 acres. Table 2 shows the crop yield

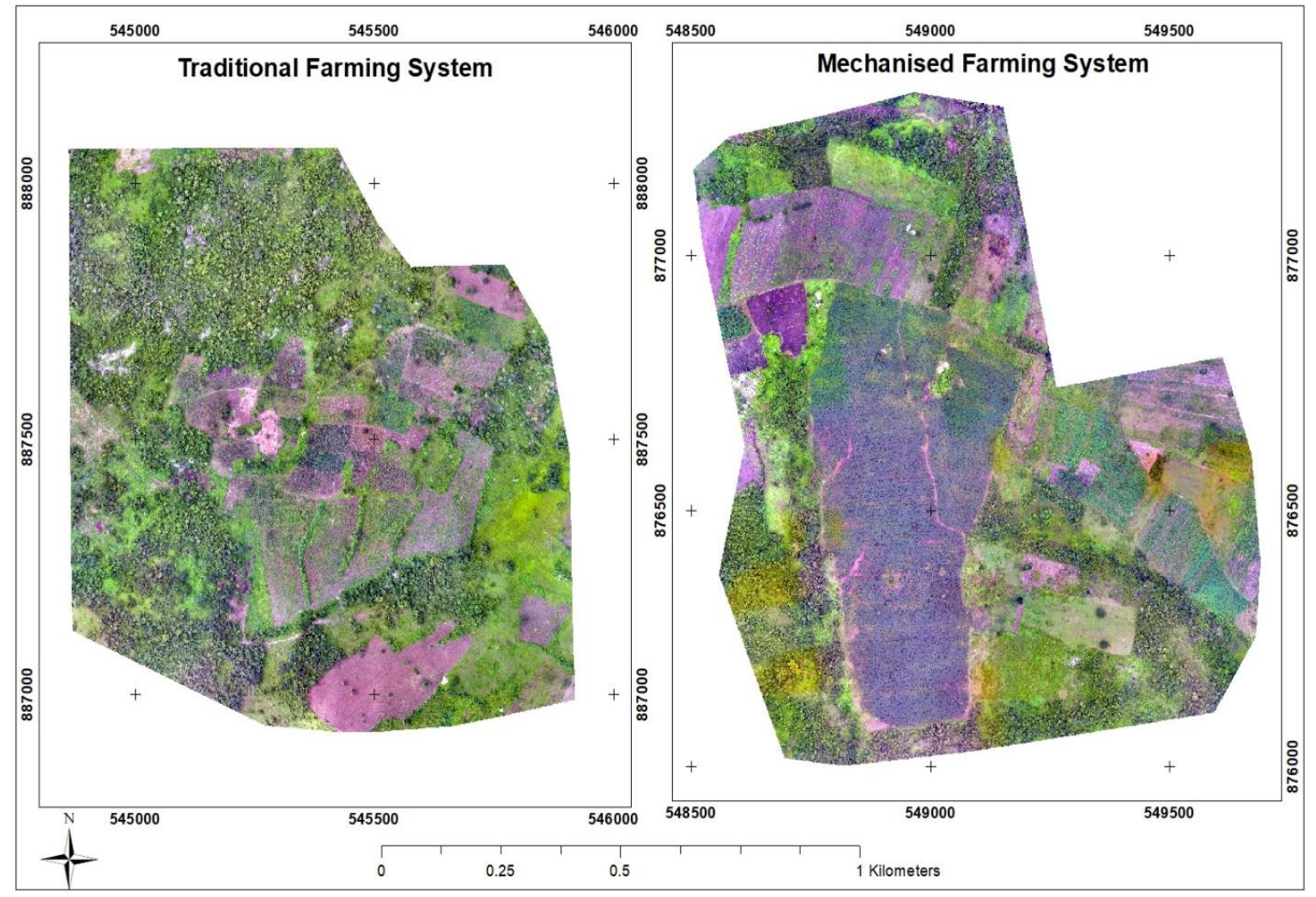

Figure 4. Digital orthomosaic showing traditional (left) and mechanised (right) farmlands

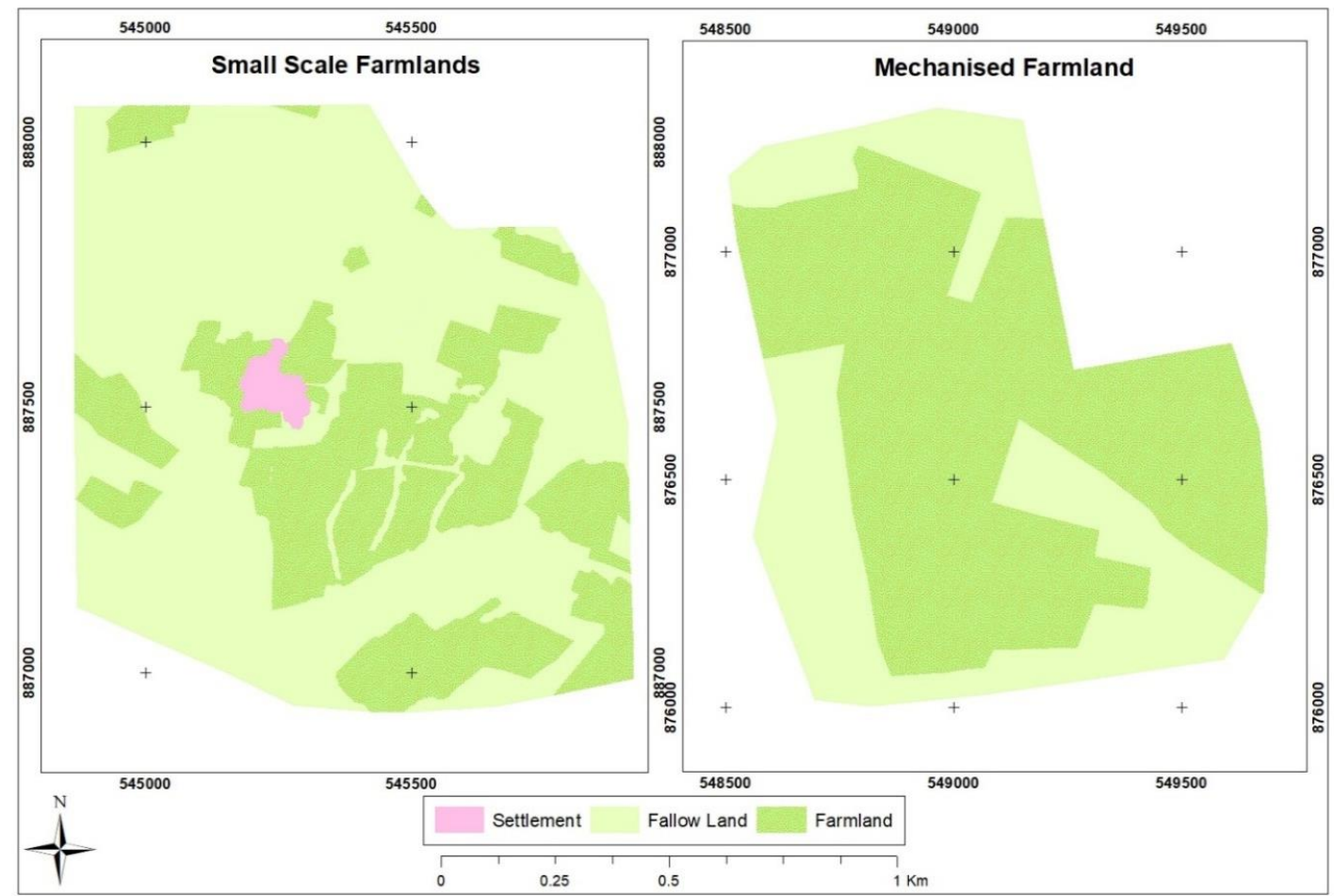

Figure 5. Crop fields digitised from the orthomosaic

Figure 5 reveals that the small-scale farms are disjointed and fragmented, and this affects the level of productivity of the farmland. Very few farmers had a shared equity on land (less than 5\%); most farms were acquired under index and productivity levels for maize and cassava. There was a sharp disparity in the CFF (traditional farms - 32.2; mechanised farms - 68.8). The productivity from the mechanised farmers for maize (184.8 tons) and cassava 
(235.6 tons) surpassed that of the traditional farmers (maize -56.9 tons; cassava -70.7 tons).
The government should encourage and support cluster farming systems using the existing farmlands thereby reducing the cost of operation, labour and equipment.

\begin{tabular}{|c|c|c|c|}
\hline Characteristic & Group & $N^{*}$ & Percentage $(\%)$ \\
\hline \multirow[t]{2}{*}{ Gender } & Male & 40 & 63.5 \\
\hline & Female & 23 & 36.5 \\
\hline \multirow[t]{4}{*}{ Age } & Below 30 yrs & 17 & 27.0 \\
\hline & Between 30 - 40 yrs & 22 & 34.9 \\
\hline & Between $40-50$ yrs & 16 & 25.4 \\
\hline & Above 50 yrs & 8 & 12.7 \\
\hline \multirow[t]{4}{*}{ Educational Level } & No Formal education & 10 & 15.9 \\
\hline & Primary education & 18 & 28.6 \\
\hline & Secondary education & 31 & 49.2 \\
\hline & University/Tertiary education & 4 & 6.3 \\
\hline \multirow[t]{5}{*}{ Size of Farmland } & Below 1 acre & 20 & 31.7 \\
\hline & Between $1-2.5$ acres & 27 & 42.9 \\
\hline & Between 2.5 - 5 acres & 6 & 9.5 \\
\hline & Between 5 - 10 acres & 8 & 12.7 \\
\hline & Above 10 acres & 2 & 3.2 \\
\hline \multirow[t]{3}{*}{ Tenure System } & Freehold & 42 & 66.7 \\
\hline & Leasehold & 18 & 28.6 \\
\hline & Shared Equity & 3 & 4.8 \\
\hline \multirow[t]{5}{*}{ Land Title } & No Title & 35 & 55.6 \\
\hline & Purchase Agreement/Receipt & 20 & 31.7 \\
\hline & Lease Agreement & 5 & 8.0 \\
\hline & Community-Issued Certificate & 1 & 1.6 \\
\hline & $\begin{array}{l}\text { Title Deed/Survey Plan/ Certificate of } \\
\text { Occupancy }\end{array}$ & 2 & 3.2 \\
\hline \multirow[t]{3}{*}{ Use of Farm Produce } & Exchange for other production & 8 & 12.7 \\
\hline & Home Consumption & 17 & 27.0 \\
\hline & Sale for Money & 38 & 60.3 \\
\hline
\end{tabular}

Table 1. Demographic and socioeconomic characteristics of the farmers $N^{*}$ - number of respondents $=63$ (Source: Questionnaire survey, 2019)

\begin{tabular}{|l|c|c|c|c|c|c|c|}
\hline Crop Type & Cropped Area & \multicolumn{2}{|c|}{ Traditional Farms } & \multicolumn{2}{c|}{$\begin{array}{c}\text { Mechanised Farm } \\
\text { Weight of } \\
\text { crops }\end{array}$} & $\begin{array}{c}\text { Crop yield } \\
\text { Index }\end{array}$ \\
\hline & (acre) & $\begin{array}{c}\text { Yield per } \\
\text { acre (tons) }\end{array}$ & $\begin{array}{c}\text { Production } \\
\text { (tons) }\end{array}$ & $\begin{array}{c}\text { Average yield } \\
\text { per acre (tons) }\end{array}$ & $\begin{array}{c}\text { Production } \\
\text { (tons) }\end{array}$ & (acre) & \\
Maize & 56.9 & 1 & 56.9 & 3.3 & 184.8 & 17.492 & 30.8 \\
Cassava & 23.6 & 3 & 70.7 & 10.0 & 235.6 & 7.068 & 30.0 \\
\hline
\end{tabular}

Table 2. Crop yield index and productivity levels for maize and cassava

\section{CONCLUSIONS}

The productivity levels between traditional farms and mechanised farms in Okeho community differ significantly. The traditional farmers will require additional resources to produce the same physical outputs with mechanised farmers at average yields. There is the need for farmers to secure their land by registration of their titles which can enable access to loan facilities from government and banks for expansion and mechanisation.
Programs geared at providing credit to farmers for input should be encouraged and this will go a long way to reduce poverty.

\section{REFERENCES}

Anyim, P., 2014. 97\% of Nigeria's land undocumented. Retrieved online on the 12th of July, 2016 at http://www.vanguardngr.com/2014/10/97-nigerias-landundocumented/ 
Benin, S., 2016. Agricultural productivity in Africa: Trends, patterns, and determinants: International Food Policy Research Institute, 386p. http://dx.doi.org/10.2499/9780896298811

Christiansen, M.P., Laursen, M.S., Jørgensen, R.N., Skovsen, S., Gislum, R., 2017. Designing and Testing a UAV Mapping System for Agricultural Field Surveying. Sensors, 17(12), 2703. https://doi.org/10.3390/s17122703

Dlamini, D., Masuku, M., 2011. Land tenure and land productivity: A case of maize production in Swaziland. Asian Journal of Agricultural Sciences, 3(4), 301-307

European Agricultural Machinery Association (2016). The use of drones in agriculture. Facst and figures. https://www.cema-

agri.org/images/publications/brochures/Flyer_QA_drone s_FFA_2016_FINAL.pdf (Date accessed: 20 ${ }^{\text {th }}$ April, 2021)

Federal Ministry of Agriculture and Rural Development (FMARD) (2016). The Agriculture at Promotion Policy (2016-2020): Building on the Successes of the ATA, Closing Key Gaps Policy and Strategy Document. Accessed online on October 1st, 2016. http://fmard.gov.ng/wp-content/uploads/2016/03/2016Nigeria-Agric-Sector-Policy- Roadmap_June-152016_Final.pdf

Frankelius, P., Norman, C., Johansen, K., 2017. Agricultural Innovation and the Role of Institutions: Lessons from the Game of Drones. Journal of Agricultural and Environmental Ethics, 1-27. Retrieved from https://doi.org/10.1007/s10806-017-9703-6

Gbopa, A.O., Ayodele, E.G., Okolie, C.J., Ajayi, A.O., Iheaturu, C.J., 2021. Unmanned Aerial Vehicles for Three-dimensional Mapping and Change Detection Analysis. Geomatics and Environmental Engineering, 15(1), 41-61. https://doi.org/10.7494/geom.2021.15.1.41

Graesser, J., Ramankutty, N., 2017. Detection of cropland field parcels from Landsat imagery. Remote Sensing of the Environnment, 201, 165-180. https://doi.org/10.1016/j.rse.2017.08.027

Hunt, E., Horneck, D., Spinelli, C., Turner, R., Bruce, A., Gadler, D., . . . Hamm, P. (2018). Monitoring nitrogen status of potatoes using small unmanned aerial vehicles. Precision Agriculture, 19(2), 314-333. Retrieved from https://doi.org/10.1007/s11119-017-9518-5

Iheaturu, C.J., Ayodele, E.G., Okolie, C.J., 2020. An Assessment of the Accuracy of Structure-from-Motion (SfM) Photogrammetry for 3D Terrain Mapping. Geomatics, Landmanagement and Landscape, no. 2, 2020, 65-82.

Iizuka, K., Itoh, M., Shiodera, S., Matsubara, T., Dohar, M., Watanabe, K., 2018. Advantages of unmanned aerial vehicle (UAV) photogrammetry for landscape analysis compared with satellite data: A case study of postmining sites in Indonesia. Cogent Geoscience, 4(1), 2018, 1498180.

https://doi.org/10.1080/23312041.2018.1498180.
Koeva, M., Muneza, M., Gevaert, C., Gerke, M., Nex, F., 2018. Using UAVs for map creation and updating. A case study in Rwanda. Survey Review, 50(361), 312-325. https://doi.org/10.1080/00396265.2016.1268756.

Kumar, P., Maddikunta, R., Hakak, S., Alazab, M., Bhattacharya, S., 2020. Unmanned Aerial Vehicles in Smart Agriculture: Applications, Requirements and Challenges. arXiv:2007.12874v1 [eess.SP].

Lahoti, S., Lahoti, A., Saito, O., 2020. Application of Unmanned Aerial Vehicle (UAV) for Urban Green Space Mapping in Urbanizing Indian Cities. [in:] Avtar R., Watanabe T. (eds.), Unmanned Aerial Vehicle: Applications in Agriculture and Environment, Springer, Cham 2020, 177-188. https://doi.org/10.1007/978-3-03027157-2 13.

Obayelu, A.E., Arowolo, A.O., Osinowo, O.H., 2017. Land Tenure, Governance and Accountability in Nigeria: The Implications on Food Production to Feed the Present and the Future. Journal for the Advancement of Developing Economies. 33. http://digitalcommons.unl.edu/jade/33

Radoglou-Grammatikis, P., Sarigiannidis, P., Lagkas, T., Moscholios, I., 2020. A compilation of UAV applications for precision agriculture. Computer Networks, $172,107148$. https://doi.org/10.1016/j.comnet.2020.107148

Ruwaimana, M., Satyanarayana, B., Otero, V.M., Muslim A., Syafiq, A.M., Ibrahim, S. et al., 2018. The advantages of using drones over space-borne imagery in the mapping of mangrove forests. PLoS ONE, 13(7), 2018, e0200288. https://doi.org/10.1371/journal.pone.0200288.

Schneider, K., Gugerty, M.K., 2011. Agricultural productivity and poverty reduction: Linkages and pathways. Libraries Test Journal, 1(1), 56-74

Tsouros, D.C., Bibi, S., Sarigiannidis, P.G., 2019. A Review on UAV-Based Applications for Precision Agriculture. Information, 10(11), 349. Retrieved from http://dx.doi.org/10.3390/info10110349 